


\title{
LIGHTWEIGHT CHAMBERS FOR THRUST CELL APPLICATIONS
}

\author{
S. Elam, M. Effinger, R. Holmes, J. Lee \\ National Aeronautics and Space Administration \\ Marshall Space Flight Center, AL \\ M. Jaskowiak \\ National Aeronautics and Space Administration \\ Glenn Research Center \\ Cleveland, $\mathrm{OH}$
}

\begin{abstract}
$\underline{\text { Abstract }}$
Traditional metals like steel and copper alloys have been used for many years to fabricate injector and chamber components of thruster assemblies. While the materials perform well, reducing engine weights would help existing and future vehicles gain performance and payload capability. It may now be possible to reduce current thruster weights up to $50 \%$ by applying composite materials. In this task, these materials are being applied to an existing thrust cell design to demonstrate new fabrication processes and potential weight savings. Two ceramic matrix composite (CMC) designs, three polymer matrix composite (PMC) designs, and two metal matrix composite (MMC) designs are being fabricated as small chamber demonstration units. In addition, a new alloy of copper, chrome, and niobium $(\mathrm{Cu}-8 \mathrm{Cr}-4 \mathrm{Nb})$ is being investigated for thrust chamber liners since it offers higher strength and increased cycle life over traditional alloys. This new alloy is being used for the liner in each MMC and PMC demonstration unit. During June-August of 2000 , hot-fire testing of each unit is planned to validate designs in an oxygen/hydrogen environment at chamber pressures around $850 \mathrm{psi}$.
\end{abstract}

Although the weight savings using $\mathrm{CMC}$ materials is expected to be high, they have proven to be much harder to incorporate into chamber designs based on current fabrication efforts. However, the PMC \& MMC concepts using the $\mathrm{Cu}-8 \mathrm{Cr}-4 \mathrm{Nb}$ liner are nearly complete and ready for testing. Additional efforts intend to use the PMC \& MMC materials to fabricate a full size thrust chamber $\left(60 \mathrm{~K} l b_{f}\right.$ thrust class). The fabrication of this full size unit is expected to be complete by October 2000 , followed by hot-fire testing in November-December 2000.

Copyright (c) 2000 by the American Institute of Aeronautics and Astronautics, Inc. No copyright is asserted in the United States under Title 17, U.S. Code. The U.S. Govemment has a royalty-free license to exercise all rights under the copyright claimed herein for Governmental Purposes. All other rights are reserved by the copyrigh owner.
Introduction

The "Lightweight, Long Life Thrust Cell" Task began in 1998 with funding under NASA Research Announcement (NRA) 8-21. The task is focused on developing technology for the Reusable Launch Vehicle (RLV) program. Although led by NASAMarshall Space Flight Center (MSFC), the team includes representatives from NASA-Glenn Research Center (GRC) and the Rocketdyne Division of The Boeing Company. Specific material systems are being developed with additional contractors, including Aerojet; Hyper-Therm; Plasma Processes, Inc. (PPI); Ceramic Composites, Inc. (CCI); MSE Technology Applications (MSE); and Lockheed Martin Astronautics (LMA) with R-Cubed Composites, Inc.

The overall objective of the task is to develop lightweight alternatives for engine thrust cells that are exposed to extreme hot gas environments. Ultimately, reducing engine weight increases vehicle performance and allows heavier payload capability. Currently, thrust cells for the RLV program's X33 engine (XRS2200 ) account for approximately $20 \%$ of the engine weight, and they're exposed to high temperature combustion products that can limit operating life. Reducing weight while overcoming thermal issues would benefit not only the RLV program, but other engine programs, as well.

The efforts undertaken in this task address material, design, and fabrication issues associated with reducing thrust cell weights, while maintaining engine requirements for life and operating conditions. Task goals include demonstrating that weight savings of at least $25 \%$ are possible by applying composite materials to the design without high fabrication costs.

Efforts were initiated by choosing an existing concept for the baseline design and reviewing its assembly for areas of potential weight savings. A variety of lightweight composite material systems are currently available, including ceramic matrix composites (CMC's), polymer matrix composites (PMC's), and 
metal matrix composites (MMC's). Various concepts with these material systems were chosen for further development. To investigate the feasibility of the selected composite materials, small chamber demonstration units are being fabricated.

In addition to composite materials, a new copper alloy available for chamber liners is also being investigated in this program. The $\mathrm{Cu}-8 \mathrm{Cr}-4 \mathrm{Nb}$ alloy potentially offers higher strength than the traditional copper alloy of NARloy-Z. This new alloy is being used for the liners in the demonstration units fabricated with the $\mathrm{PMC}$ and MMC material systems.

Each demonstration unit will be evaluated by testing it under appropriate cold flow and hot-fire conditions. Based on the fabrication efforts and test results, selected composite materials will be used to fabricate a full size "lightweight" version of the baseline design. Hot-fire testing of this full size unit is planned for late 2000 , at the end of the task.

Included in this report are details of the baseline design; a review of the materials, fabrication processes, and test plans for each subscale demonstration unit; and a summary of additional task plans.

\section{Baseline Design}

The X33 engine's thrust cell was initially chosen as the baseline design. Figure 1 illustrates its dimensions and operating parameters. It represents a typical thrust cell design made with conventional techniques and materials.

Designed and fabricated by Rocketdyne, this unit operates with Liquid Oxygen (LOX) and Gaseous Hydrogen $\left(\mathrm{GH}_{2}\right)$ at a nominal chamber pressure of 850 psi for 250 seconds. The thrust cell assembly includes an injector and combustion chamber. The injector is made of stainless steel (SS) for the LOX and $\mathrm{GH}_{2}$ manifolds and NARloy- $Z$ for the faceplate.

The chamber consists of a NARloy- $Z$ liner machined with coolant channels and surrounded in its midsection by stainless steel throat supports. These components are slipped into the stainless steel structural jacket, which includes the manifolding that distributes liquid hydrogen $\left(\mathrm{LH}_{2}\right)$ to the liner for cooling. Braze processes are used to bond the components together.

The weight breakdown in Figure 1 shows the chamber weighs close to 61 pounds, while the injector adds

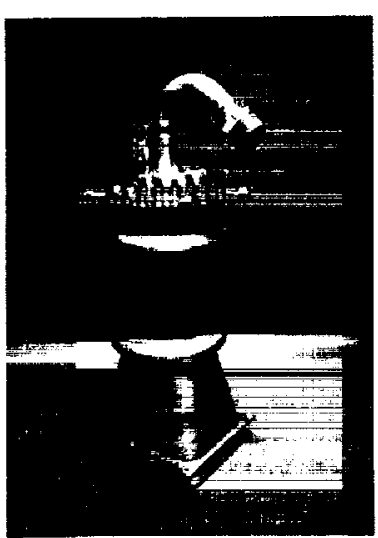

Design/Operating Conditions -

\begin{tabular}{|l|c|}
\hline Injector Assy Weight & $14.4 \mathrm{lbs}$ \\
Chamber Assy Weight & $60.8 \mathrm{lbs}$ \\
Liner & $14.8 \mathrm{lbs}$ \\
Jacket & $33.3 \mathrm{lbs}$ \\
Throat Supports & $12.7 \mathrm{lbs}$ \\
\hline Nom. Pc & $\sim 850 \mathrm{psi}$ \\
Max. Pc & $\sim 1000 \mathrm{psi}$ \\
Mission Duration & $250 \mathrm{sec}$ \\
\# of starts & 22 \\
\hline
\end{tabular}

Figure 1. X33 Thrust Cell - Baseline Design
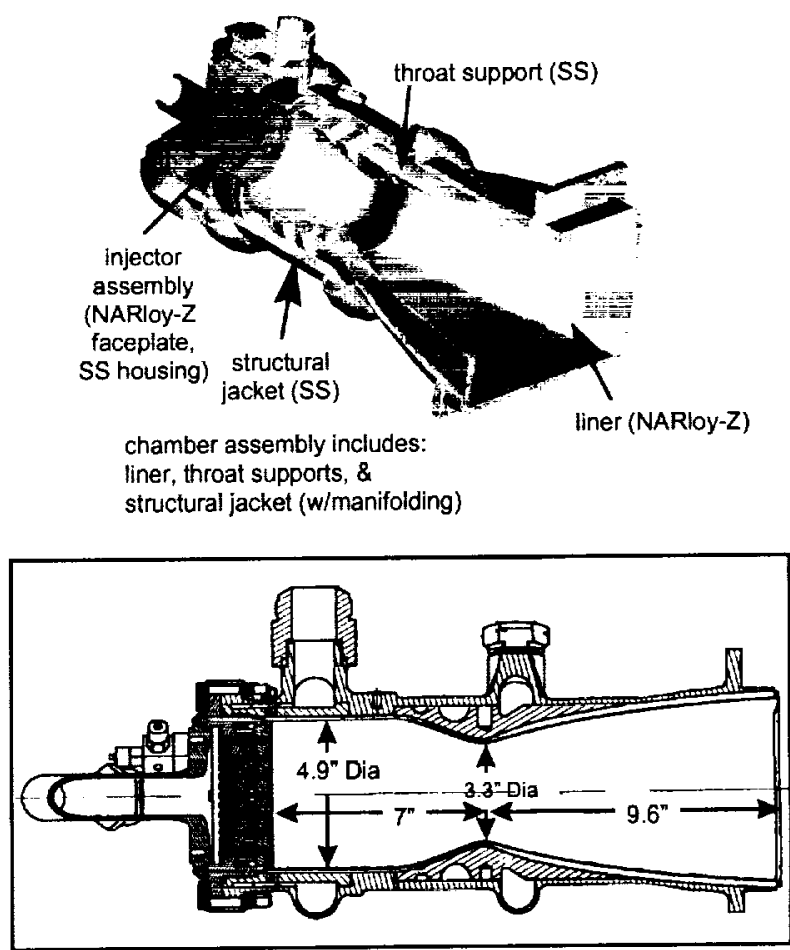
about 14 pounds to the thrust cell assembly. Since each X33 engine uses 20 thrust cells, reducing the weight of each by even $25 \%$ would generate a significant weight savings for the 2 -engine vehicle.

Although the weight of the $\mathrm{X} 33$ thrust cell design was optimized for its application, it used traditional metal materials and fabrication processes in its assembly. In this task, its design was reviewed to determine potential areas of weight savings with composite materials. A successful "lightweight" design would be at least $25 \%$ lighter and still operate with the same requirements shown in Figure 1. Although "low" cost was not a primary objective, material systems and processes would not be considered viable if they greatly exceeded the cost of the baseline.

Due to funding limitations, task efforts were focused only on the chamber component of the thrust cell. Since $80 \%$ of the thrust cell weight is found in the chamber, reducing its weight would provide the biggest payoff for the assembly. A review of potential materials created multiple options for the chamber design:

Option 1) Replace the NARloy-Z liner with a high temperature CMC material that could be reinforced with an appropriate composite structural layer and manifolding.

Option 2) Retain the copper alloy liner and replace the stainless steel structural jacket and manifolding with an appropriate PMC or MMC material system.

Material concepts for these options were considered from numerous vendors. Each concept was reviewed relative to cost, technical risk, schedule, and potential payoff. Eventually seven concepts were chosen for further development, including two $\mathrm{CMC}$, three PMC, and two MMC systems.

\section{Composite Chamber Demonstration Units}

Each of the chosen material systems is being developed by making subscale chamber demonstration units similar to the illustration in Figure 2. All units include an actively cooled surface 5 inches long with a throat diameter of 1.5 inches. Inlet and exit manifolds were required for distributing coolant with appropriate structural supports surrounding the unit. Liquid hydrogen will be supplied for cooling, with inlet pressures of 1300-1800 psi. Table I summarizes the material systems being developed with selected contractors.

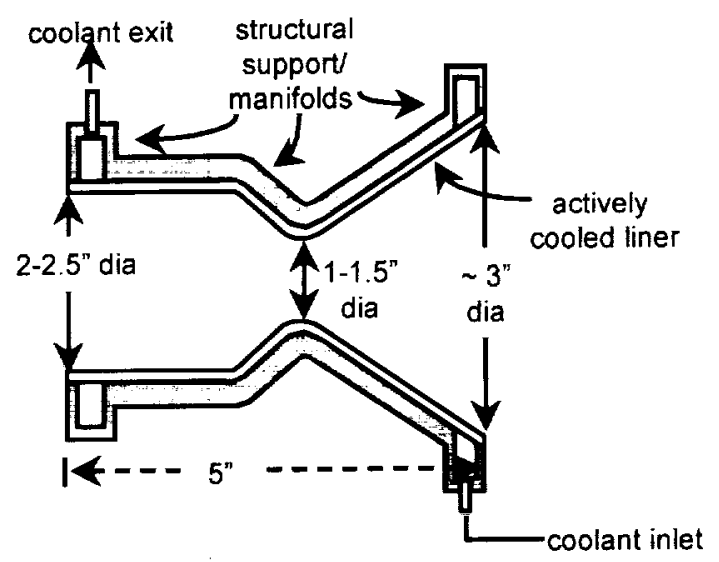

Figure 2. Size of Chamber Demonstration Units

Table I. Summary of Chosen Composite Concepts

Option 1: CMC concepts - actively cooled systems that replace copper alloy liner (and steel structural supports)

\begin{tabular}{|c|l|}
\hline Supporting Contractor & \multicolumn{1}{c|}{ Materials } \\
\hline Hyper-Therm, Inc. & SiC/SiC liner with annular ring of woven coolant channels \\
\hline Ceramic Composites, Inc. (CCI) & C/C liner surrounded by copper tubing \\
\hline
\end{tabular}

Option 2: PMC \& MMC concepts - structural systems that replace stainless steel around copper alloy liner

\begin{tabular}{|c|l|}
\hline Supporting Contractor & \multicolumn{1}{c|}{ Materials } \\
\hline Aerojet & Graphite fiber/epoxy resin overwrap \& Inconel manifolds \\
\hline Plasma Process, Inc. (PPI) & Graphite fiber/epoxy resin overwrap \& stainless steel manifolds \\
\hline LMA/R-cubed & Graphite fiber/epoxy resin overwrap \& molded graphite manifold \\
\hline MSE-Technology Applications, Inc. (MSE) & One piece casting of Al/SiC structural jacket and manifolds \\
\hline Plasma Processes, Inc. (PPI) & $\begin{array}{l}\text { Vacuum Plasma Sprayed (VPS) Al/SiC structural jacket \& } \\
\text { machined Al/SiC manifolds }\end{array}$ \\
\hline
\end{tabular}

Note: Silicon Nitride $\left(\mathrm{Si}_{3} \mathrm{~N}_{4}\right)$ offers a ceramic option for a structural system, but this material was not included in this task because it is being pursued by Rocketdyne and the Air Force under a separate program. 


\section{CMC Units for Option 1}

Originally, this task was proposed for NRA8-21 to take advantage of the high temperature capability offered by lightweight CMC's. Similar materials are being investigated for nozzle ramp designs on the X33 engine. While these materials look promising for nozzle ramps, applying them to combustion chambers is more challenging. Not only is the chamber's shape more complicated, the heating rates in the chamber are much higher than those along the nozzle ramp.

If CMC's could be successfully fabricated for the chamber, they could potentially withstand hot gas wall temperatures two to three times hotter than conventional copper alloy liners. Unfortunately, these materials are inherently porous, so overcoming their permeability to properly contain the hydrogen coolant is a primary technical concern.

After reviewing the CMC concepts offered by many vendors, two were selected for development in this task: a silicon carbide ( $\mathrm{SiC}$ ) matrix from Hyper-Therm and a carbon (C) matrix from CCI. [Note that for these demonstration units, efforts are currently focused on creating a successful CMC liner. The manifolding and structural support for either unit have not necessarily been optimized; they just provide an appropriate interface with existing test facilities to properly evaluate the liner.]

\section{SiC/SiC Concept from Hyper-Therm}

Hyper-Therm's concept provides an actively cooled continuous fiber-reinforced $\mathrm{SiC}$ matrix with chemical vapor infiltration (CVI). Specifically, the materials include a bi-axially braided HI-Nicalon ${ }^{\circledR}$ SiC fiber-reinforced CVI$\mathrm{SiC}(\mathrm{SiC} / \mathrm{SiC})$. They proposed $\mathrm{SiC} / \mathrm{SiC}$ because of its high conductivity and its mechanical properties at elevated temperatures.

The completed structure will consist of a thin inner layer, an annular array of integral trapezoidal cooling channels separated by thin radial webs, and a relatively thick outer primary structural layer. A copper coating will be electrodeposited on the inner surface of the cooling channels to appropriately contain the hydrogen coolant.

Figure 3 shows their liner preform with the annular ring of coolant channels incorporated into the assembly. The completed assembly is expected to be ready for hot-fire testing by June 2000.

\section{C/C Concept from $\mathrm{CCI}$}

$\mathrm{CCI}$ is creating a cooled $\mathrm{C} / \mathrm{C}$ matrix with a graded layer of rhenium ( $\mathrm{Re})$. They proposed $\mathrm{C} / \mathrm{C}$ for its low thermal expansion, high thermal conductivity, and high temperature strength. Initially, their matrix and processing included a thin layer of Re on the interior surface to protect the carbon fibers from an oxidizing environment. However, materials testing determined that the $\mathrm{Re}$ alone would not be adequate. So, to further insure oxidation protection, the Re interior will be coated with tantalum (Ta).

The completed assembly will be cooled with copper tubes brazed to the composite material. The copper tubes help eliminate concerns about
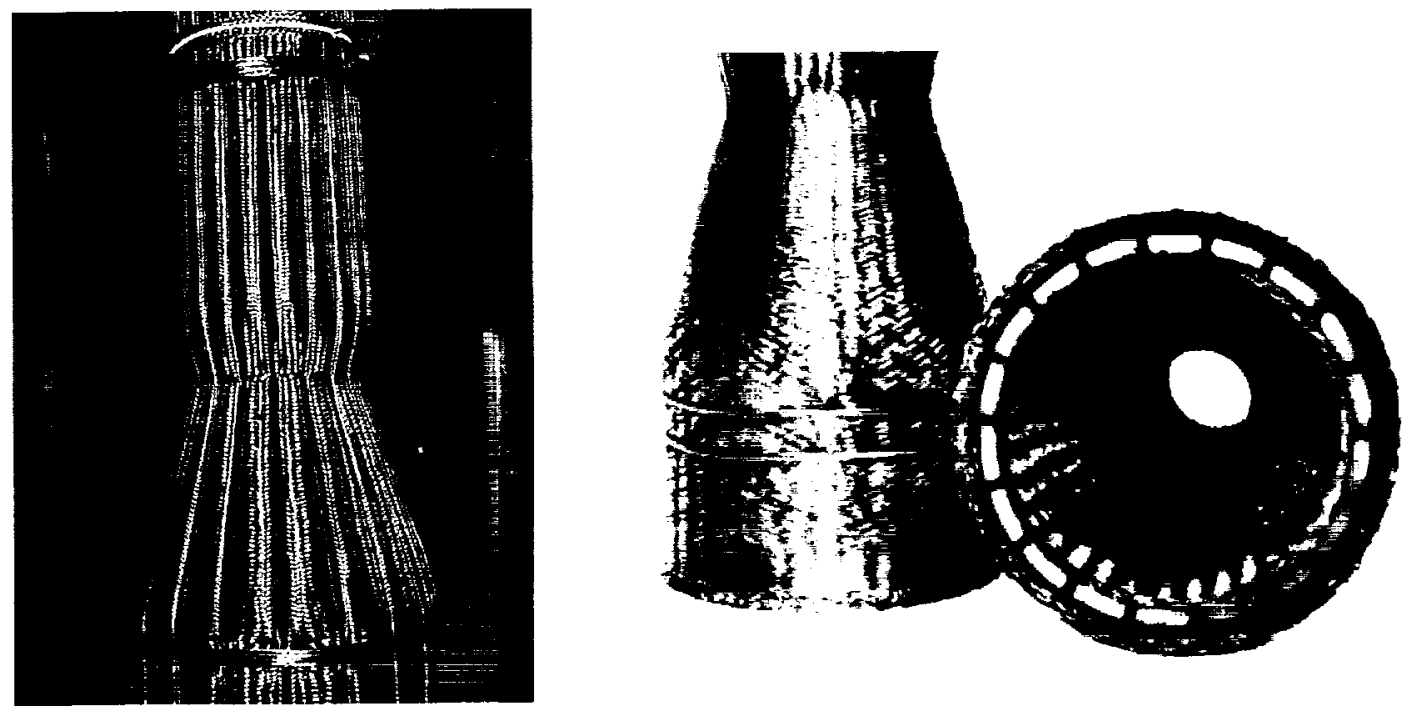

Figure 3. Hyper-Therm's SiC/SiC liner with annular array of coolant channels 
containing the hydrogen coolant. Yet, successfully brazing the copper to the carbon composite offers a significant fabrication challenge. The completed assembly from $\mathrm{CCI}$ is also expected to be ready for hot-fire testing by June 2000.

\section{$\underline{\text { PMC \& MMC Units for Option } 2}$}

Although CMC's potentially offer attractive weight savings and higher temperature capability, they currently present the greatest fabrication and operation challenges. Since the bulk of the weight of the chamber assembly is due to the structural supports and manifolding, significant weight savings can be achieved with less technical risk by retaining the copper alloy liner and reducing the weight around it with a high strength PMC or MMC system.

The major fabrication issue associated with this approach is successfully bonding the composite structure to the copper alloy liner. The composite system must accommodate the coefficient of thermal expansion (CTE) of the copper alloy liner to maintain the bond during operation (when cryogenic and hot-fire conditions cause the liner to expand and contract). To ensure the structural integrity of a composite unit, appropriate strength and stiffness are also required.

Based on the concepts proposed by various vendors, several PMC \& MMC options were chosen for development in this task. The PMC concepts incorporate graphite fiber overwraps, while the MMC concepts use a matrix of aluminum (Al) reinforced with silicon carbide ( $\mathrm{SiC}$ ). Each of these concepts includes a $\mathrm{Cu}-8 \mathrm{Cr}-4 \mathrm{Nb}$ liner.

\section{PMC Concepts - Graphite/Epoxy Overwraps}

Many vendors proposed similar graphite/epoxy overwrap designs, but the processes offered by Aerojet, PPI, and LMA/R-cubed were eventually selected for development. For each unit, manifolds will be bonded to the forward and aft ends of the liner. Select carbon fibers will then be wrapped around the remaining surface of the liner. An epoxy resin will be applied to reinforce the wrapped fibers and create a structural jacket.

Although the concepts are similar, each contractor uses slightly different fiber/resin materials and processing techniques. In addition, while Aerojet and PPI are using Inconel and stainless steel manifolds, respectively, LMA/Rcubed offer a composite manifold at the forward end of their unit.
Shown in Figure 4, this composite manifold is made from a molded compound of chopped graphite fibers (Lytex 4149). Table II shows this material offers high strength at a fraction of the weight of stainless steel.

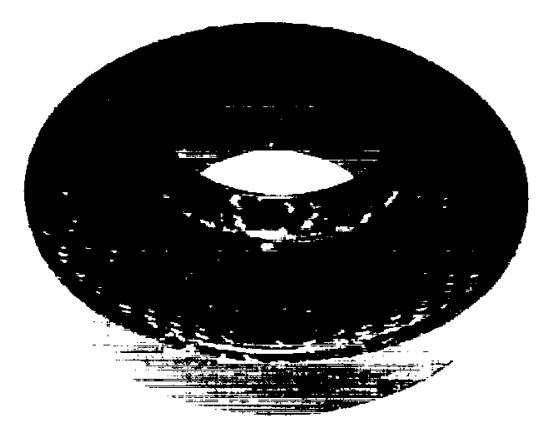

Figure 4. Molded Graphite Manifold Prior to Final Machining

Table II. Strength \& Density of Lytex 4149 Compared to Stainless Steel

\begin{tabular}{|c|c|c|}
\hline $\begin{array}{c}\text { Specific Strength } \\
\left(\mathrm{ksi} / \mathrm{lb}_{\mathrm{m}} / \mathrm{in}^{3}\right)\end{array}$ & 258 & 808 \\
\hline $\begin{array}{c}\text { Specific Stiffness } \\
\left(\mathrm{Msi} / \mathrm{lb}_{\mathrm{m}} / \mathrm{in}^{3}\right)\end{array}$ & 97 & 154 \\
\hline $\begin{array}{c}\text { Density } \\
\left(\mathrm{lb}_{\mathrm{m}} / \mathrm{in}^{3}\right)\end{array}$ & 0.29 & 0.05 \\
\hline
\end{tabular}

The structural overwrap concepts may potentially offer as much as $80 \%$ weight savings for the thrust cell chambers. Strategically wrapping the structure maximizes the strength of the fibers to handle the high hoop stress of the chamber assembly.

\section{$\underline{\text { MMC Concepts - Al/SiC }}$}

Both MMC concepts offer up to $65 \%$ weight reductions by using a matrix of aluminum reinforced with $\mathrm{SiC}$ particulates $(17 \%$ by volume in PPI's material and $20 \%$ by volume in MSE's material). Resulting material properties are compared with stainless steel in Table III. Although the materials in each MMC unit are similar, their fabrication processes are significantly different. 
Table III. Metal Matrix Composite Material Properties Compared to Stainless Steel

\begin{tabular}{|c|c|c|c|c|c|}
\hline Material & As used in... & $\begin{array}{c}\text { CTE } \\
\left.\left[\text { in/(in }{ }^{\circ} \mathrm{F}\right) \times 10^{-6}\right]\end{array}$ & $\begin{array}{l}\text { Density } \\
\left(\mathrm{lb}_{\mathrm{m}} / \mathrm{in}^{3}\right)\end{array}$ & $\begin{array}{c}\text { Specific } \\
\text { Strength } \\
\left(\mathrm{ksi} / / \mathrm{l}_{\mathrm{m}} / \mathrm{in}^{3}\right)\end{array}$ & 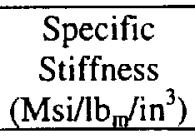 \\
\hline Stainless Steel 347 & Baseline design & 9.3 & 0.29 & 258 & 96.5 \\
\hline $\begin{array}{c}\text { DWA Al/SiC } \\
\text { (17\% SiC by volume) }\end{array}$ & PPI's manifolds & 9.3 & 0.107 & 542 & 138 \\
\hline $\begin{array}{c}\text { VPS ed } \mathrm{Al} / \mathrm{SiC} \\
\text { (17\% SiC by volume) }\end{array}$ & $\begin{array}{l}\text { PPI's structural } \\
\text { jacket }\end{array}$ & 9.3 & 0.107 & 314 & 65.4 \\
\hline $\begin{array}{c}\text { Cast } \mathrm{Al} / \mathrm{SiC} \\
(20 \mathrm{SiC} \text { by volume) }\end{array}$ & $\begin{array}{l}\text { MSE's one piece } \\
\text { casting }\end{array}$ & 9.0 & 0.108 & 445 & 140 \\
\hline
\end{tabular}

Specific Strength = (llimate tensile strength/density

Specilic Stiffness = Morlulus of Elasticity/density

PPI applies Al/SiC powder directly to the liner using the Vacuum Plasma Spray (VPS) process, which is depicted in Figure 5. A thin layer of litanium is sprayed between the jacket and the liner to create a diffusion barrier and help bond the $\mathrm{Al} / \mathrm{SiC}$ to the copper. Manifolds are machined from billets of $\mathrm{Al} / \mathrm{SiC}$ and bonded directly to the liner at each end.

MSE creates the $\mathrm{Al} / \mathrm{SiC}$ jacket around the liner in a "one-step" brazing/casting process. As shown in Figure 6, the liner is prepared with a braze material on its outer surface and placed in a casting mold. Soluble salt cores are positioned around the aft and forward end of the liner to create the required plenums of the manifolding. Molten $\mathrm{Al} / \mathrm{SiC}$ is poured into the mold, and while the jacket is cast, it is simultaneously brazed to the liner.

\section{$\underline{\mathrm{Cu}-\mathrm{Cr}-\mathrm{Nb} \text { Liner }}$}

Material studies at GRC, MSFC, and Rocketdyne suggest that $\mathrm{Cu}-8 \mathrm{Cr}-4 \mathrm{Nb}$ provides an alternative to NARloy-Z for combustion chamber liners. NARloy-Z

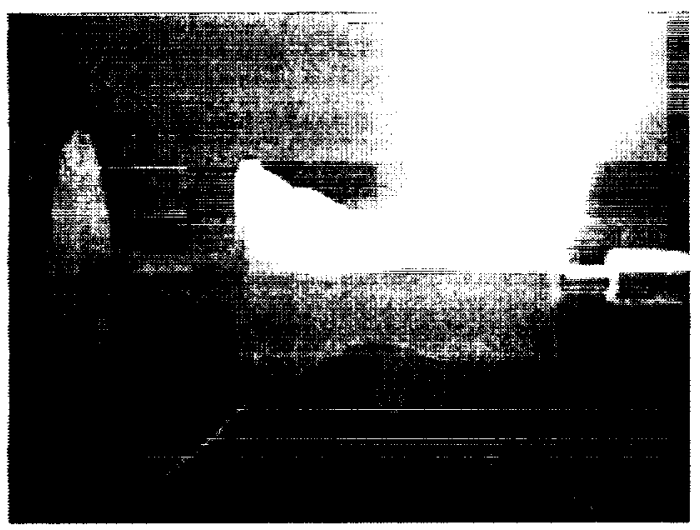

Figure 5. A structural layer of Al/SiC applied to the liner using the VPS process in PPI's unit (an alloy of copper, silver and zirconium) is currently used in many chamber designs, including components of the X33 thrust cell and the Space Shuttle Main Engine (SSME). It provides high thermal conductivity, but its high mechanical strength eventually decreases with higher temperatures.

In comparison, $\mathrm{Cu}-8 \mathrm{Cr}-4 \mathrm{Nb}$ has a higher strength at elevated temperatures, increasing expected low cycle fatigue (LCF) life. The thermally induced stresses are not as high for this alloy at elevated temperatures because its CTE is lower. A liner made with this alloy could potentially operate $200^{\circ} \mathrm{F}$ hotter and maintain properties equivalent to a NARloy- $Z$ liner. Operating at higher temperatures may reduce chamber cooling requirements and pressure losses. Table IV compares the current material properties of extruded $\mathrm{Cu}-8 \mathrm{Cr}-4 \mathrm{Nb}$ with NARloy-Z based on testing at GRC.

Rocketdyne has successfully fabricated a $\mathrm{Cu}-8 \mathrm{Cr}-4 \mathrm{Nb}$ liner using powder metallurgy processing. They incorporated the liner into a completed chamber assembly fabricated under a joint program with the Air Force. Although the hardware has been fabricated, it has not yet been hot-fire tested.

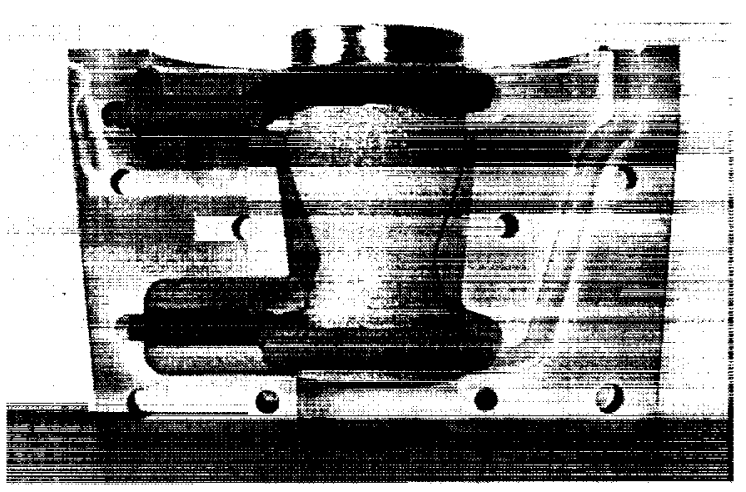

Figure 6. Prepared liner and cores positioned in casting mold for MSE's unit. 
Table IV. Cu-8 Cr-4 Nb Material Properties Compared to NARloy-Z

\begin{tabular}{|c|c|c|c|c|c|}
\hline Material & $\begin{array}{c}\text { Density } \\
\left(\mathrm{lb}_{\mathrm{m}} / \mathrm{ft}^{3}\right)\end{array}$ & $\begin{array}{c}\text { Thermal } \\
\text { conductivity* }^{*} \\
\left(\mathrm{BTU} / \mathrm{in}-\mathrm{s}^{-}{ }^{-} \mathrm{F}\right)\end{array}$ & $\begin{array}{c}\text { Yield } \\
\text { Strength* } \\
(\mathrm{ksi})\end{array}$ & $\begin{array}{c}\text { Tensile } \\
\text { Strength* } \\
(\mathrm{ksi})\end{array}$ & $\begin{array}{c}\text { CTE } \\
{\left[\mathrm{in} /\left(\mathrm{in}-{ }^{0} \mathrm{~F}\right) \times 10^{-6}\right]}\end{array}$ \\
\hline NARloy-Z (wrought) & 570 & 0.0047 & 13 & 17 & 10.5 \\
\hline Cu-8Cr-4Nb (extruded) & 543 & 0.0040 & 17 & 22.5 & 9.3 \\
\hline $\begin{array}{c}\text { Cu-8Cr-4Nb processed } \\
\text { with VPS }\end{array}$ & 545 & 0.0040 & 23 & 27 & $\mathrm{n} / \mathrm{a}$ \\
\hline
\end{tabular}

* Properties at $1000^{\circ} \mathrm{F}$

In contrast, MSFC is fabricating liners with this material using the VPS process. Current material properties for $\mathrm{Cu}-8 \mathrm{Cr}-4 \mathrm{Nb}$ processed with VPS are included in Table IV. VPS processing allows a functional gradient coating to be included on the liner's hot wall. The resulting thermal barrier coating provides oxidation protection to further reduce liner temperatures and increase cycle life. Analytical results predict hot wall temperatures can be reduced as much as $200^{\circ} \mathrm{F}$ with an appropriate coating, such as $\mathrm{NiCrAlY}$.

Although thermal barrier coatings are commonly applied to prevent oxidation and blanching in chamber liners, they don't always prove useful. Generally, they are applied as a separate layer to the hot wall after the liner is completed. Depending on how well the coating is applied and the operating environment of the chamber, such coatings can easily spall off and delaminate after just a few tests - locally exposing the hot wall and disrupting the boundary layer on the surface.

However, PPI can spray the coating and liner in a continuous graded deposition process, making the coating an integral part of the liner. With this process, the bond strength between the liner and the coating increases significantly.

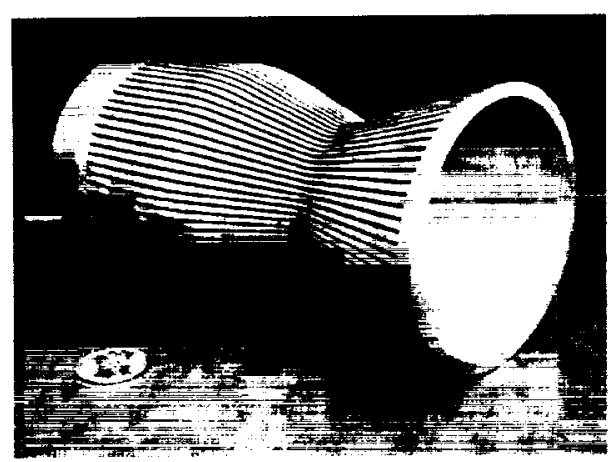

(a)
To help support the material developments of this new alloy, MSFC supplied one liner made with $\mathrm{Cu}-8 \mathrm{Cr}$ $4 \mathrm{Nb}$ and a functional gradient coating of NiCrAlY for each MMC and PMC unit. PPI was contracted to fabricate these liners using the VPS process.

For each liner, the $\mathrm{Cu}-8 \mathrm{Cr}-4 \mathrm{Nb}$ and NiCrAlY were sprayed onto mild steel mandrels. Coolant channels were machined into the resulting liner and filled before spraying an additional layer of copper to close out the coolant channels. Coolant distribution rings were machined at each end to expose the channels. After removing the channel filler, each liner was heat treated in a HIP cycle before removing the mandrels with a final machining and etching process. Figure 7 shows a VPS'ed liner machined with coolant channels and closed out.

In the baseline (X33) thrust cell design, the coolant channels are not closed out. Instead, the structural jacket is brazed directly to the channel lands of the liner. However, providing a closeout on these demonstration unit liners allows additional surface area for bonding the composite structural jackets. It also lowers the temperatures at the composite/copper interface since the resulting bond joint is extended further away from the hot wall. The extra fabrication

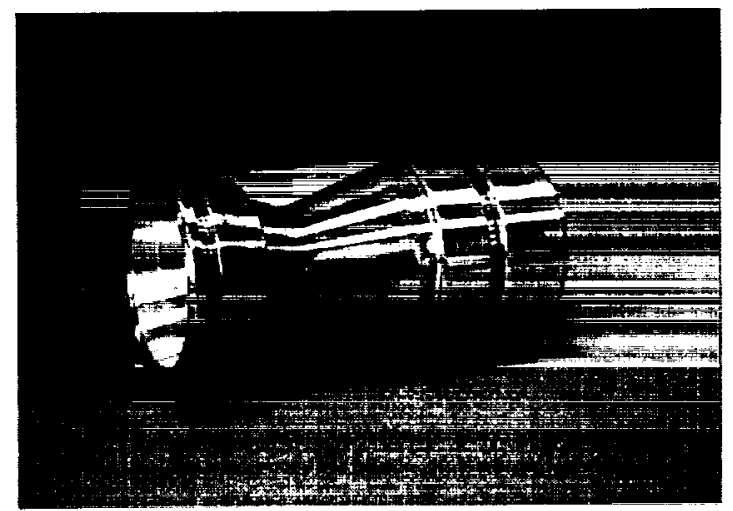

(b)

Figure 7. A VPS'ed liner with (a) machined coolant channels and (b) closed out. 
step to close out the liners does not add significant cost to the assembly, since the VPS process is low cost compared to other fabrication methods.

\section{$\underline{\text { Test Plans }}$}

Test facilities are available at both GRC and MSFC for evaluating these subscale chambers in appropriate oxygen/hydrogen combustion environments. The CMC units were designed to interface with GRC's facility, while the PMC and MMC units were designed for testing at MSFC.

Since actively cooled CMC materials have never been used as chamber liners before, the main test objective for these units is to demonstrate how well they handle a high temperature, oxygen/hydrogen environment with combustion temperatures reaching $6500^{\circ} \mathrm{F}$. Testing is planned with gaseous oxygen (GOX) and $\mathrm{GH}_{2}$ at chamber pressures up to 1000 psi.

Hyper-Therm and CCI will provide three deliverable units of their concept. These units are expected to be available for testing at GRC in June 2000. Each unit will be appropriately leak checked and proof tested prior to delivery. Twenty to thirty hot-fire tests are planned for each concept with test durations from 3250 seconds.

For the PMC and MMC units, the main test objective is to demonstrate the integrity of the composite/copper alloy bond joint when exposed to cryogenic and hotfire conditions. Each unit will first be exposed to cryogenic cycle testing by flowing liquid nitrogen $\left(\mathrm{LN}_{2}\right)$ through its coolant system. The $\mathrm{LN}_{2}$ will flow long enough to "cold soak" the hardware. Each unit will be cycled between ambient and cryogenic temperatures at least five times. Nondestructive evaluation (NDE) techniques will then be used to evaluate the bond joint between the composite material and the copper alloy liner.

Each PMC and MMC unit that survives the cryogenic cycle testing with an acceptable bond joint will be hotfire tested. The hot-fire tests will be performed with LOX and $\mathrm{GH}_{2}$ at chamber pressures around 850 psi for at least 5 seconds. The bond joints will be checked again after the hot-fire testing.

One deliverable unit of each PMC and MMC concept is expected to be available for testing at MSFC by June 2000. Each unit will be leak checked and proof tested prior to delivery.

\section{Additional Task Plans}

Although testing the CMC materials in this task is expected to provide useful and unique information, the fabrication efforts to date suggest these materials need a lot more development before they can actually be applied to required chamber designs. Yet, the PMC and $\mathrm{MMC}$ concepts already appear feasible. In order to fabricate a full size thrust cell chamber by the end of 2000 , preliminary designs are being developed based on the PMC and MMC subscale units. The fabrication of a full size chamber with one or both of these material systems is expected to be complete in late 2000 and followed by appropriate hot-fire testing.

In addition, to support the RLV program's VentureStar design, a linear chamber concept is also being pursued with these materials. The fabrication of this chamber concept is expected to be complete in late 2000 . If funds are available, hot-fire testing on this concept will be performed, as well.

\section{Full Size Composite Thrust Cell Chamber}

Originally, the task intended to create a full size composite chamber for the $\mathrm{X} 33$ thrust cell, which was the initial baseline design. However, the baseline design for the full size hardware was eventually changed to the assembly shown in Figure 8. This alternate thrust cell design was fabricated by Rocketdyne in a joint program with the Air Force funded by IHPRPT (Integrated High-Payoff Rocket Propulsion Technology) to demonstrate advanced fabrication processes. The "IHPRPT" thrust cell is similar in design and size to the X33 concept, and

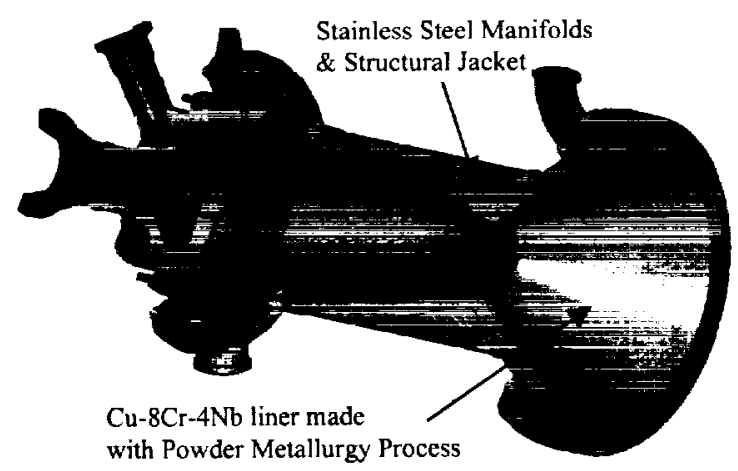

Chamber Diameter $=4.4^{\prime \prime}$

Throat Diameter $=2 "$

Length from injector face to throat $=8.35 \mathrm{~m}$

$P_{c}(\max )=2400$ psi

Coolant $=$ Liquid hydrogen

Figure 8. Thrust Cell Fabricated by Rocketdyne under IHPRPT Program. 
includes the $\mathrm{Cu}-8 \mathrm{Cr}-4 \mathrm{Nb}$ liner made with the powder metallurgy process, surrounded by stainless steel for structural supports and manifolding.

By making the full size composite chamber compatible with the "IHPRPT" thrust cell, it can be evaluated with hot-fire testing at a higher chamber pressure (2400 psi vs. $1000 \mathrm{psi}$ for the X33 design). Also, to incorporate the composite materials effectively, modifications to the X33 design would have been necessary to move the inlet manifold from the throat area to the aft end. Since the "IHPRPT" design already provided the desired manifold configuration, significant time and money will be saved in the task design efforts.

Rocketdyne and the Air Force offered the use of the IHPRPT hardware for testing. The existing injector and chamber assembly will be hot-fire tested at MSFC first to evaluate performance and operation. When the full size composite chamber is completed, it will be tested with the same injector to provide a direct performance and weight comparison between a current "state of the art" chamber and a potential lightweight, composite alternative.

The design of the full size composite chamber will include a VPS $\mathrm{Cu}-8 \mathrm{Cr}-4 \mathrm{Nb}$ liner with functional gradient coating of NiCrAlY on the hot wall. For the structural system, two designs are being considered. Both designs currently include $\mathrm{Al} / \mathrm{SiC}$ manifolds bonded at each end of the liner. One design considers a PMC overwrap for the structural jacket, while the other would use $\mathrm{Al} / \mathrm{SiC}$ applied with the VPS process.

The $\mathrm{Al} / \mathrm{SiC}$ casting offered by MSE is attractive, and the test results on the completed demonstration unit are eagerly awaited. However, in order to complete the fabrication of the full size unit by late 2000 , it is not possible to consider an $\mathrm{Al} / \mathrm{SiC}$ casting due to limitations in MSFC's procurement process.

\section{Composite Linear Thrust Cell Chamber}

Of course, the IHPRPT chamber profile does not include a rectangular exit plane like the X33 thrust cell. While this task would like to demonstrate that composite materials can accommodate this profile change, efforts to add a rectangular exit plane to the planned full size design would be cost and time prohibitive.

In order to address issues related to a rectangular configuration, the task added a parallel effort to design and fabricate a linear profiled (2-D) chamber. Figure 9 illustrates the basic profile of this composite linear chamber's preliminary design.

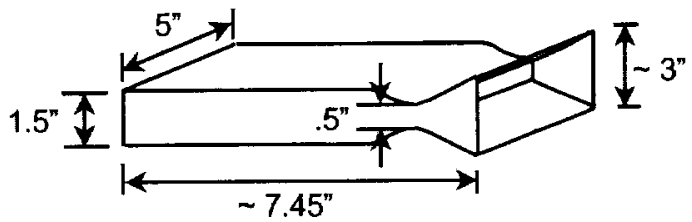

(a)

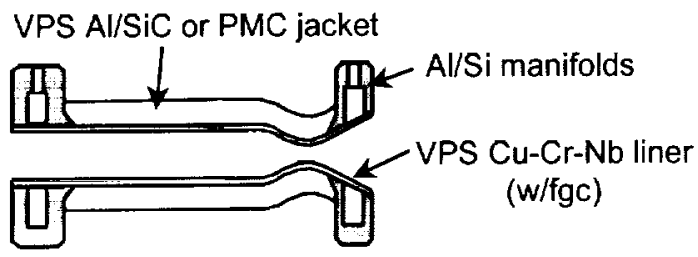

(b)

Figure 9. Proposed Linear chamber (a) Profile and (b) Materials

The preliminary design includes a VPS'ed copper alloy liner and manifolds machined from $\mathrm{Al} / \mathrm{SiC}$. The VPS process will be used again to apply $\mathrm{Al} / \mathrm{SiC}$ for the structural jacket. A second unit may be attempted that provides a PMC overwrap for the structural jacket.

Since the RLV program's VentureStar engine has currently baselined the use of linear thrust cells, this effort hopes to demonstrate "lightweight" options for the design. Hot-fire testing on the linear chamber will be performed in late 2000 if funds become available.

Although a linear liner has never been created with the VPS process, recent spray runs have shown excellent results on practice parts. Figure 10 shows a machined sample from a rectangular structure sprayed by Rocketdyne in MSFC's VPS facility. For this part, NARloy-Z was sprayed on a rectangular steel pipe, which acted as the required mandrel.

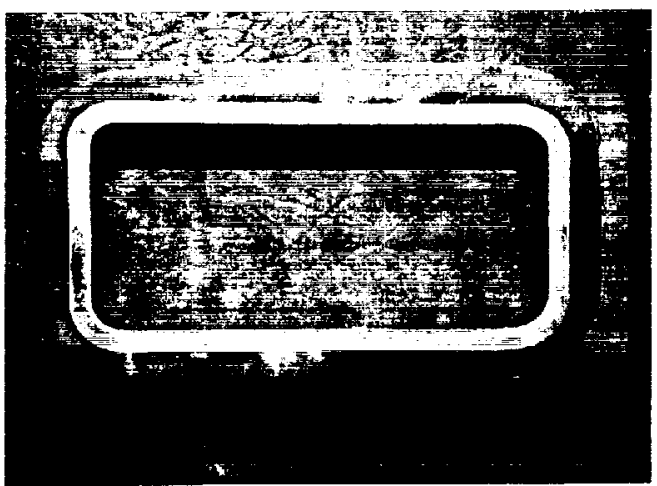

Figure 10. Sample of NARloy-Z VPS'ed on Rectangular Steel "Mandrel" 
Even in this initial attempt, the VPS material showed excellent density in photomicrographs, and the material adhered well to the rounded corners. These initial efforts provide confidence that the VPS process can successfully create the required liners and structural jackets for the linear chamber.

\section{$\underline{\text { Summary }}$}

A variety of lightweight materials have been pursued in this development task. The small chamber units provide an early demonstration of the required fabrication processes to evaluate the feasibility of each material concept. The CMC materials have proven to be challenging in the fabrication efforts, but the deliverable units are eagerly awaited to pursue hot-fire testing and demonstrate their temperature capabilities.

The PMC and MMC concepts offer significant weight savings with less technical risk. Each of these material systems will be included in the preliminary designs of the full size thrust cell chamber. Test results on their demonstration units will help finalize the design of the full size unit. Preliminary fabrication results and materials testing provide enough confidence in the $\mathrm{Cu}$ $8 \mathrm{Cr}-4 \mathrm{Nb}$ material to baseline its use in the full size chamber liner.

All demonstration units are expected to be completed by June 2000 and hot-fire tested soon after delivery. Fabrication efforts on the full size chamber and the linear chamber are expected to be complete by October 2000. Hot-fire testing on the full size chamber is planned for November-December 2000. When the task is complete, the weight savings available with composite materials will be quantified, along with estimated fabrication costs to apply the materials and processes to flight hardware.

\section{Acknowledgements}

The authors would like to thank the many employees of Rocketdyne at Canoga Park, CA, and Huntsville, AL, who've supported this task since it began. Their efforts have provided significant contributions in the areas of analysis, design, and fabrication. Special thanks go to those supporting MSFC's VPS facility for their help in fabricating the chamber liners and additional hardware for this task.

\section{$\underline{\text { References }}$}

Wherley, B., Ulmer, D., Claflin, S. \& Farner, B., "Injector and Combustion Chamber Technology Advances Demonstrated on the Thrust Cell Technologies Program", $35^{\text {th }}$ AIAA/ASME/SAE/ASEE Joint Propulsion Conference, Los Angeles, CA, June 1999, AIAA 99-2749.

Elvander, J., Wherley, B., Claflin, S. \& Farner, B., "Development of a Lightweight Thrust Chamber Assembly Utilizing In-Situ Reinforced Silicon Nitride", $35^{\text {th }}$ AIAA/ASME/SAE/ASEE Joint Propulsion Conference, Los Angeles, CA, June 1999, AIAA 99-2897.

Material Properties of Extruded $\mathrm{Cu}-8 \mathrm{Cr}-4 \mathrm{Nb}$ (GRCop84) provided by D. Ellis, Case Western Reserve University, Cleveland, OH, May 2000. 